\title{
THE STRUCTURAL MOTIVATION OF PALATALIZATION
}

\section{A MOTIVAÇÃO ESTRUTURAL DA PALATALIZAÇÃO}

\author{
LA MOTIVACIÓN ESTRUCTURAL DE LA PALATALIZACIÓN
}

Elisa Battisti*

Universidade Federal do Rio Grande do Sul/CNPq

\section{Ben Hermans**}

Meertens Institute/Vrije Universiteit-Amsterdam

\begin{abstract}
This paper is about the structural motivation of the palatalization of coronal stops in Brazilian Portuguese (BP) and cross-linguistically. It aims to explain why (a) coronal stop consonants are the typical targets of the process, (b) coronal stops are the only targets of the process in BP, (c) the typical trigger of palatalization crosslinguistically is the coronal high vowel, (d) the only trigger of the process in BP is the coronal high vowel. We propose an internal structure of segments with abstract elements $\mathrm{C}$ and $\mathrm{V}$ (VAN DER HULST, 2005, 2011) and show that the consonantality of high front vocoids is the motivation of palatalization. The process tends to affect consonants which are similar to the trigger in structural terms. The proposal allows us to distinguish secondary and full palatalization (BATEMAN, 2007) structurally. It also explains the selection of trigger and targets of palatalization in BP, which results of full palatalization, a kind of palatalization which demands maximally identical trigger and targets.
\end{abstract}

KEYWORDS: Dependency-based phonology. Internal structure of segments. Palatalization of coronal stops. Brazilian Portuguese.

RESUMO: Este artigo trata da motivação estrutural da palatalização de consoantes plosivas coronais em português brasileiro (PB) e nas línguas do mundo. O objetivo é explicar por que (a) as plosivas coronais são o alvo típico do processo, (b) as plosivas coronais são o único alvo do processo em $\mathrm{PB}$, (c) o gatilho típico da palatalização nas línguas do mundo é a vogal alta coronal , (d) o único gatilho do processo em PB é a vogal alta coronal. Propomos uma estrutura interna dos segmentos com os elementos abstratos $\mathrm{C} e$ V (VAN DER HULST, 2005, 2011) e mostramos que a consonantalidade dos vocoides anteriores altos é a motivação estrutural da palatalização. O processo tende a afetar consoantes semelhantes ao gatilho em termos estruturais. A proposta permite distinguir estruturalmente a palatalização secundária e a palatalização plena (BATEMAN, 2007). Também explica a seleção de gatilhos e alvos de palatalização em $\mathrm{PB}$, que resultam de palatalização plena, um tipo de palatalização que exige gatilhos e alvos maximamente idênticos.

PALAVRAS-CHAVE: Fonologia baseada em dependência. Estrutura interna dos segmentos. Palatalizaçao das plosivas coronais. Português brasileiro.

\footnotetext{
*Professor of Linguistics (UFRGS - Federal University of Rio Grande do Sul, Brazil), researcher of CNPq - The Brazilian National Councilfor Scientific and Technological Development. E-mail:battisti.elisa@com.br.

** Professor of Phonology (VU-Adam - Vrije Universiteit-Amsterdam), researcher of Meertens Institute, The Netherlands.E-mail:ben.hermans@meertens.knaw.nl.
} 
RESUMEN: Este artículo aborda la motivación estructural de la palatalización de las consonantes oclusivas coronales en portugués brasileño (PB) y en las lenguas del mundo. El objetivo es explicar por qué (a) las oclusivas coronales son el objetivo típico del proceso, (b) las oclusivas coronales son el único objetivo del proceso en $\mathrm{PB}$, (c) el desencadenante típico de la palatalización es la vocal coronal alta /i/, (d) el único desencadenante del proceso em PB es la vocal coronal alta. Proponemos una estructura interna de los segmentos con los elementos abstractos C y V (VAN DER HULST, 2005, 2011) y mostramos que la consonantalidad de los vocoides anteriores altos es la motivación estructural de la palatalización. El proceso tiende a afectar consonantes similares al desencadenante en términos estructurales. La propuesta permite distinguir estructuralmente la palatalización secundaria y la palatalización completa (BATEMAN,2007). También explica la selección de desencadenantes y objetivos de palatalización en PB, que resultan de la palatalización completa, un tipo de palatalización que requiere desencadenantes y objetivos máximamente idénticos.

PALABRAS CLAVE: Fonología basada en la dependencia. Estructura interna de los segmentos. Palatalización de las oclusivas coronales. Portugués brasileño.

\section{INTRODUCTION}

This paper ${ }^{1}$ concerns the phonological representation of processes and segments. It is an attempt to explain typological facts in a purely phonological (abstract) way. It approaches palatalization cross-linguistically and the regressive palatalization of $/ \mathrm{t}, \mathrm{d} / \mathrm{in}$ Brazilian Portuguese (BP). The paper aims to (i) provide structural motivation for palatalization cross-linguistically; (ii) explain why coronal stops are the typical targets and high vocoids are the typical triggers of palatalization; (iii) represent secondary and full palatalization as structurally different processes; (iv) explain the restricted selection of trigger and targets of palatalization in BP.

Palatalization is a phonological process by which consonants acquire secondary palatal articulation or shift their primary place to, or close to, the palatal region, generally under the influence of an adjacent front vowel (KOCHETOV, 2011). In typological terms, two contexts of palatalization are distinguished (BATEMAN, 2007; KOCHETOV, 2011): morphophonological (restricted to certain morphological forms) and phonological contexts (across the board, or unrestricted morphologically). Palatalization processes are also differentiated regarding their effects on the target segment: there is secondary palatalization (the segment acquires secondary articulation) and full palatalization (with change in primary place of articulation, or in place and manner of articulation).

According to Bateman (2007), high front vowel /i/ and palatal glide / $\mathrm{j} /$ are the typical triggers of palatalization, but only /i/ is implicationally related to other possible triggers of the process: if /e/ triggers palatalization in a certain language, /i/ also does. The triggers of palatalization generally follow the target (regressive palatalization) and are not deleted. The typical targets of palatalization are consonants $/ \mathrm{t} \mathrm{d} /$. The most frequent targets of full palatalization are consonants $/ \mathrm{t} \mathrm{d} \mathrm{kg} \mathrm{s} \mathrm{n} /$ and of secondary palatalization are consonants / $\mathrm{t} \mathrm{kg} \mathrm{s} \mathrm{p} \mathrm{b} \mathrm{m/.} \mathrm{There} \mathrm{is} \mathrm{an} \mathrm{implicational} \mathrm{relation} \mathrm{over} \mathrm{targets} \mathrm{regarding} \mathrm{the} \mathrm{kind} \mathrm{of} \mathrm{palatalization,} \mathrm{secondary} \mathrm{or} \mathrm{full:}$ if labial consonants are targets of palatalization in a certain language, they are only secondarily palatalized and dorsal consonants as well as coronal consonants are targeted by full or secondary palatalization.

Regarding palatalization cross-linguistically, previous proposals (CLEMENTS; HUME, 1995; MORÉN, 2003; van der HULST, 2005, for example) of phonological representation conceive the process as the spreading of a place feature from a front vowel to the preceding consonant, generally a plosive. Nonetheless, they do not provide the structural motivation of the process.

Considering the typology of palatalization and its phonetic manifestations, palatalization seems to be a process driven by the constriction of the triggering vowel (BATEMAN, 2007; KOCHETOV, 2011; BERNS, 2013), which has effects on the preceding consonant. The challenge is explaining why certain degrees of vowel constriction trigger palatalization. Another challenge is explaining why certain segments are better targets of palatalization than other segments and why structurally different kinds of palatalization (secondary and full) exist.

${ }^{1}$ A Portuguese version of the paper (BATTISTI; HERMANS, 2016) was published in the journal Lingüistica 32, 2016:, p.61-75. 
Palatalization in BP is full phonological palatalization, with change in place and manner of articulation. Examples are in (1). In BP, palatalization affects only typical targets of the process and is triggered only by the typical trigger.

(1) Palatalization in BP: examples

\begin{tabular}{|c|c|}
\hline a. Underlying /i/ & \\
\hline tipo 'kind' & ['t fipv] \\
\hline tijolo 'brick' & [tfízolv] \\
\hline prático 'practical' & ['pratfikv] \\
\hline dica 'hint' & ['d 3 ike] \\
\hline dinheiro 'money' & [dzi'nerv] \\
\hline médico 'phisician' & ['medzikv] \\
\hline
\end{tabular}

b. Derived [i]

teatro 'theater' [ $\mathrm{t} f$ i'atro]

noite 'night' ['nojt $\left.\int \mathrm{I}\right]$

delícia 'delight' [d 3 i'lisje]

onde 'where' ['o $\mathrm{o}^{\mathrm{n}} \mathrm{d}_{3 \mathrm{I}} \mathrm{I}$

Palatalization is allophonic in BP, applying across the board. It is a categorical process in at least half of the Brazilian capital cities (CARDOSO et al., 2014). It targets coronal stops /t,d/ and it is triggered by a following high front vowel, either underlyingly present (1a) or derived from vowel /e/ in unstressed positions (1b). The outputs are palato-alveolar consonants [ty,ds].

Previous analyses of palatalization in BP (BISOL; HORA, 1993; MONARETTO; QUEDNAU; HORA, 2005; CRISTÓFAROSILVA, 2003, 2012; PAGOTTO, 2001) do not explain the selection of coronal plosives as the only targets of palatalization in BP and the high front vowel as the only trigger. Besides that, they represent the process in two steps, the first of them secondary palatalization, generally not attested in $\mathrm{BP}^{2}$.

The present paper will answer the following questions:

(a) Why are there different kinds of palatalization cross-linguistically, secondary and full?

(b) Why is /i/ the prototypical trigger, /e/ the second best trigger? Why are/t, d/ the prototypical targets, /k, g/ the second best targets?

(c) Why are obstruents (stops more than fricatives) better targets than nasals, followed by laterals, and finally by rhotics? Why are labials secondarily palatalized only?

(d) Why coronal plosives / $/$ and / d/ form a natural class regarding palatalization in BP?

(e) Why only the high front vowel /i/ triggers palatalization in BP?

The analysis follows the hypothesis that both typical triggers and targets of palatalization are highly consonantal. The high degree of consonantality of the typical triggering vowel motivates the spreading of its consonantal features to the preceding consonant because a consonant is a better licenser of consonantal features than a vowel is. Prototypical targets of palatalization are highly consonantal segments and so very similar (in elemental terms) to the typical trigger.

\section{FORMALISM}

As Kochetov (2011, p.1686) claims, analyzing palatalization has challenged scholars in part due to the use of traditional featural representations, as the one by Clements and Hume (1995), for example. This paper makes use of a theory of feature organization that departs from classical feature theory: Radical CV Phonology, by van der Hulst $(2005,2011)^{3}$. Elements C and V rather than

\footnotetext{
${ }^{2}$ The only registers of secondary palatalization in BP are found in the variety spoken in Florianópolis (PAGOTTO, 2001; BRAGANÇA; AZEVEDO, 2015), derived from Azorean Portuguese. Secondarily palatalized [ts],[dz] variants alternate with fully palatalized [t]], [dz], but the fully palatalized variants are more frequently attested then secondarily palatalized ones in such a variety of BP.

${ }^{3}$ Radical CV Phonology is one of the theories of phonological representation based on the idea that dependency relations are central aspects in the organization of phonological structure. This idea originated in two models, Dependency Phonology (ANDERSON; EWEN, 1987) and Government Phonology (KAYE; LOWENSTAMM; VERGNAUD, 1985). Structural relations hold between heads and dependents, similar to the ones that syntactic constituents hold: the head governs its dependents. Rather than features, the primes of those approaches are unary, monovalent entities. In Dependency Phonology, primes are called components, in Government Phonology, elements. Van der Hulst $(2005,2011)$ calls them elements, the label adopted in this paper.
} 
features are used. However, differently from Radical CV Phonology, elements C and V are not combined nor interpreted in syllable structure.

The proposal in this paper is combining $\mathrm{C}$ and $\mathrm{V}$ elements in an internal structure of segments organized in nodes. The nodes are equivalent to the class nodes of Feature Geometry (CLEMENTS, 1985 and other studies in this line). We will show that (i) the motivation of palatalization is the hybrid character of the trigger - the consonantality of the high front vowel, that is, its high degree of constriction, despite of its vocalic nature; (ii) the selection of targets of palatalization relates to the structural identity between triggering vowel and targeted consonant.

Unary elements C and V (van der HULST, 2005), devoid of phonetic content, and one single geometry are used to represent the internal structure of both consonants and vowels. Phonological primes $\mathrm{C}$ and V lack phonetic concreteness, but 'stand for' phonetic (acoustic and articulatory) properties (van der HULST, 2005). Their interpretation is derivable from their position in the phonological structure, as well as from their combination in that position.

A segment is a tripartite, binary branching structure under a root node, as in (2): consonants are C-root segments, vowels are V-root segments. According to Botma (2004), manner is the core of the segment (positions $\circ$ ): manner is obligatory, it selects place (positions $\square$ ) and phonation (positions $\diamond$ ). Place is a dependent of manner, phonation is a specifier (the most optional component). Extra branching of place and phonation $(\square, \nabla)$ is very restricted ${ }^{4}$. A node is maximally binary at every level. The implication is that any node can only have maximally two daughters.

(2) Internal structure of segments

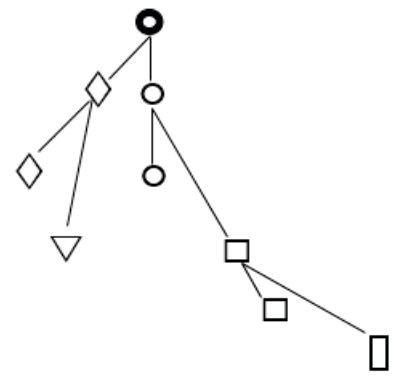

( $\mathbf{O}$ = root position; $\odot=$ manner position; $\square=$ place position; $\diamond=$ phonation position; $\square, \nabla=$ complex place and phonation positions)

Manner, place and phonation positions are filled with elements $\mathrm{C}$ and $\mathrm{V}$. Different combinations of elements $\mathrm{C}$ and $\mathrm{V}$ in those structural positions represent distinctive properties of consonants and vowels. Generally, C represents constriction/consonantality, $\mathrm{V}$ represents sonorancy/vocality. For example, segments with high degree of constriction, like stops, have both manner positions filled with elements C. Fricatives, less constricted than stops, have one of their manner positions filled with an element V. The same holds for place and phonation positions, now representing properties of these structural dimensions of segments.

A possible version of the combinations of elements $\mathrm{C}$ and $\mathrm{V}$ in different structural positions is in (3). It is sufficient to represent segmental contrasts that are relevant to the present analysis of palatalization in $\mathrm{BP}$ and other languages ${ }^{5}$. Combinations that represent properties of consonants, segments with C-root (C-Manner, C-Place, C-Phonation), are in (3a). In (3b), one sees

\footnotetext{
${ }^{4}$ Binarity of constituent structure is a basic idea of Government Phonology (KAYE; LOWENSTAMM; VERGNAUD, 1985) followed by van der Hulst (2011) and adopted here.

${ }^{5}$ Not every language will have the whole set of combinations. Combinations in (3) may be reviewed relatively to the specific properties they represent in a certain language, depending on the existing contrasts.
} 
combinations that represent properties of vowels, segments with V-root (V-Manner, V-Place, V-Phonation). This version follows van der Hulst (2005), but with some differences ${ }^{6}$.

Concerning consonants (3a) and their manner properties, Cc represents stopness, $\mathrm{Cv}$, fricativeness, $\mathrm{Vv}$, sonorancy. Regarding place properties, Cc represents coronality, Cv, post-coronality, Vc, dorsality, Vv, labiality. Regarding phonation properties, Cc represents voicelessness, $\mathrm{Vv}$, voicedness in consonants which are Cc-manner and Cv-manner. In Vv-manner consonants, C(c) combinantion in phonation represents nasality.

Concerning vowels (3b) and their manner properties, Cc represents highness, Cv, mid highness, Vc, mid lowness and Vv, lowness. Regarding place properties, Cc represents frontness, $\mathrm{Cv}$, front roundness, $\mathrm{Vc}$, back frontness, $\mathrm{Vv}_{\mathrm{v}}$, back roundness. Regarding phonation properties, the different possible combinations represent tone distinctions.

(3) Segmental properties represented by the combinations of elements $\mathrm{C}$ and $\mathrm{V}^{7}$

(a)

\begin{tabular}{|c|c|c|c|}
\hline \multirow[b]{2}{*}{ C-Manner } & \multirow[b]{2}{*}{ C-Place } & \multicolumn{2}{|c|}{ C-Phonation } \\
\hline & & $C c, C v, V c-m a n n e r$ segments & $\begin{array}{c}V v \text {-manner } \\
\text { Segments }\end{array}$ \\
\hline $\mathrm{Cc}=$ stopness & $\mathrm{Cc}=$ coronality & $\mathrm{Cc}=$ voicelessness & $\mathrm{Cc}=$ nasality \\
\hline \multirow[t]{2}{*}{$\mathrm{Cv}=$ fricativeness } & $\mathrm{Cv}=$ post-coronality & $\mathrm{Cv}=$ breathiness & \\
\hline & $\mathrm{Vc}=$ dorsality & $\mathrm{Vc}=$ creakiness & \\
\hline $\mathrm{Vv}=$ sonorancy & $\mathrm{Vv}=$ labiality & $\mathrm{Vv}=$ voicedness & \\
\hline
\end{tabular}

(b)

\begin{tabular}{|c|c|c|}
\hline V-Manner & V-Place & $V$-Phonation (tone) \\
\hline $\mathrm{Cc}=$ highness & $\mathrm{Cc}=$ frontness & $\mathrm{Cc}=$ upper raised \\
\hline $\mathrm{Cv}=$ mid highness & $\mathrm{Cv}=$ front roundness & $\mathrm{Cv}=$ upper non-raised \\
\hline $\mathrm{Vc}=$ mid lowness & $\mathrm{Vc}=$ back frontness & $\mathrm{Vc}=$ non-upper raised \\
\hline $\mathrm{Vv}=$ lowness & $\mathrm{Vv}=$ back roundness & $\mathrm{Vv}=$ non-upper non-raisec \\
\hline
\end{tabular}

Examples of the internal structure of some consonants and vowels are in (4a) and (4b) respectively.

\footnotetext{
${ }^{6}$ The present analysis does not take syllable structure to be lexical. Onset-Manner and Rhyme-Manner combinations are not distinguished. The representation of nasality of nasal consonants is still under discussion. According to Botma (2004), nasality could be represented by an element $\mathrm{V}$ in a single phonation position of nasal consonants if one took nasals to be obstruents ( $\mathrm{Cc}$ or $\mathrm{Cv}$-Manner segments). For the purposes of the present analysis, nasals are considered to be sonorants (Croot segments with both manner positions filled with $\mathrm{V}$ elements), nasality being represented by C elements in C-Phonation.

${ }^{7}$ As in van der Hulst $(2005,2011)$, the combination of elements and their relative status (head or dependent) is registered in capital letter (head) and lowercase letter (dependent), as in Cc, for example. The relation between head and dependent(s) is not crucial to the present analysis, but it is assumed here.
} 
(4) Examples

(a)

$$
\begin{aligned}
& \text { stopness } \\
& \text { coronality }
\end{aligned}
$$

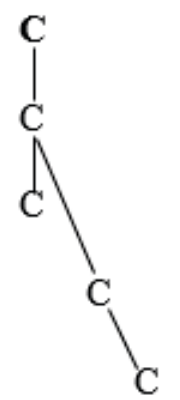

/t

(b)

$$
\begin{aligned}
& \text { highness } \\
& \text { frontness }
\end{aligned}
$$

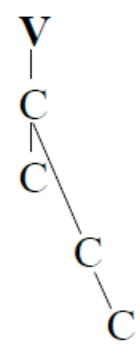

/i/

$$
\begin{aligned}
& \text { stopness } \\
& \text { dorsality }
\end{aligned}
$$

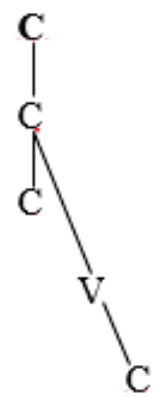

$/ \mathrm{k}$
mid highness
frontness

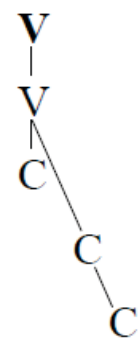

/e/

$\begin{array}{ll}\text { fricativeness } & \text { sonorancy } \\ \text { coronality } & \text { coronality }\end{array}$

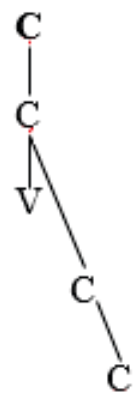

$/ \mathrm{s} /$

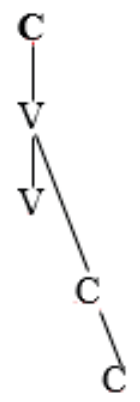

/1/ lowness
backness

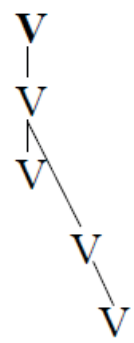

/a/

Using the formalism just presented, we will show that the high degree of constriction (consonantality) of coronal vowels is the motivation of palatalization, a process that affects preferably consonants with an internal structure maximally similar to the internal structure of the triggering vowel.

\section{ANALYSIS}

According to the formalism just presented (section 2), palatalization results from the spreading of C-elements from the vowel onto the preceding consonant. Two structurally distinct palatalization processes (secondary and full palatalization) result from such spreading, depending on the kind of C-element that spreads.

\subsection{DIFFERENT KINDS OF PALATALIZATION}

Place is a branching structure. Secondary palatalization derives from the spreading of the lowest ${ }^{8} \mathrm{C}$-place element of a vowel (5a). Full palatalization results from the spreading of the highest C-place element of a vowel (5b).

${ }^{8}$ The lowest C-place element of a vowel is maximally distant from the root node. 
If palatalization is spreading of a C-element, it is predicted that yet another kind of full palatalization is possible. It involves the spreading of the C-manner element which is the daughter of the root node. In this case, all C elements of the vowel spread onto the preceding consonant $(5 \mathrm{c})$.

One expects that $\mathrm{C}$ elements of a vowel spread to a consonant that has its relevant structural positions also filled with $\mathrm{C}$ elements. See the representations in (6).

Target and trigger in (6a) and (6b) are minimally different - both are Cc-Place, but the target is Cv-Manner and the trigger, CcManner. Target and trigger are totally identical in (6c), a kind of full palatalization that is only possible with trigger /i/ and targets /t, $\mathrm{d} /$.

(5) Palatalization: general schema

a, Secondary palatalization

Full palatalization

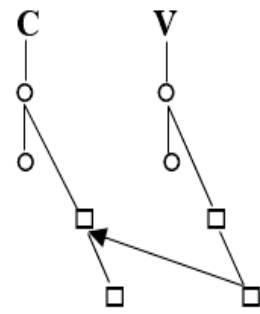

(6) Palatalization: more 'concrete' schema

a. Secundary palatalization

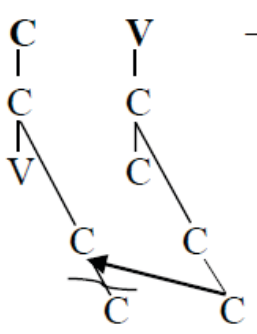

/s/ /i/

b. Full palatalization

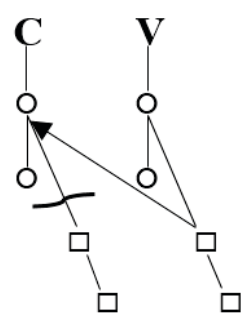

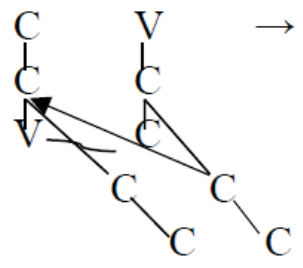

/S/

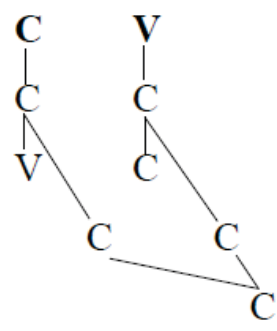

$\left[\mathrm{s}^{\mathrm{j}} \mathrm{i}\right]$

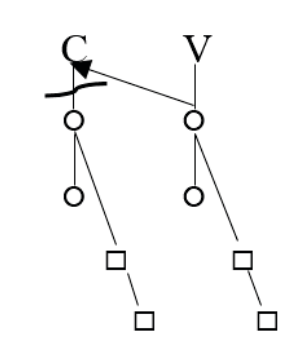

c. Full palatalization under maximally identical trigger ang target 
c. Full palatalization involving totally identical (manner+place features) trigger and target

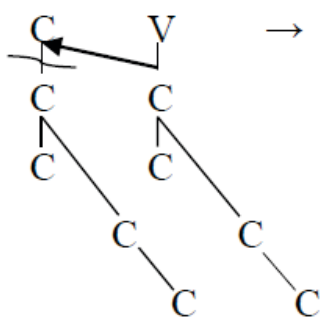

$/ \mathrm{t} / \quad$ i/

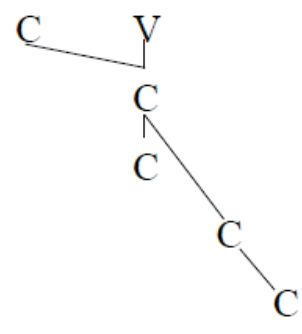

$\left[\mathrm{t} \int 1\right]$

The claim in this analysis is that palatalization favours targets that are similar to the trigger. This gives rise to what we call 'change without change $^{9}$ : the spreading of a C element to a position already filled with a C element is more of a substitution than a change. Substitution does not count as change in the sense of the theory of Faithfulness (see footnote 9). It is implied by the fact that a segment (root node) cannot have two manner-daughters, neither can a manner node have two place-daughters. The same holds at the lowest level of the place node. A place node, therefore, can have maximally one place element, at least in BP. Consequently, spreading implicates the deletion of the structure already attached to the anchor before spreading.

Relevant positions of target consonants may be filled with $\mathrm{V}$ elements. Two outcomes of the spreading of $\mathrm{C}$ are possible in this case: (7a) and (7a.i), maintenance of the $\mathrm{V}$ elements of the target, resulting in a complex structure (secondary palatalization); (7b) and (7b.i), delinking of the $\mathrm{V}$ elements of the target (full palatalization with change).

(7) Palatalization that gives origin to complex structures and palatalization with change
a. Secondary palatalization
b. Full palatalization
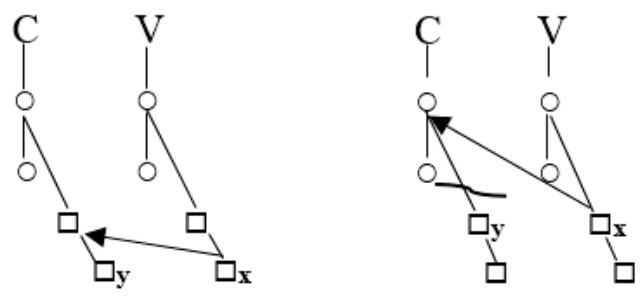

a.i
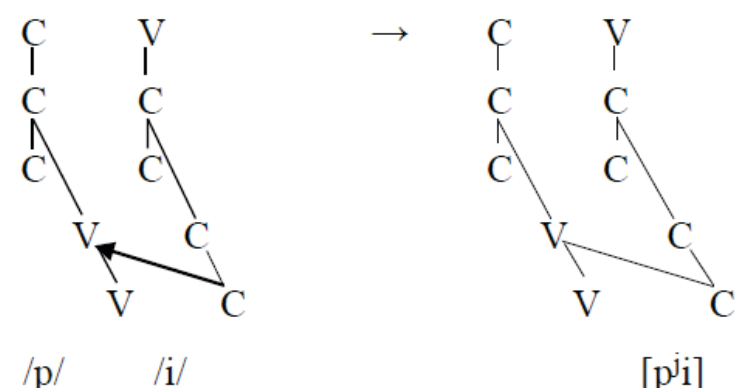

$\left[\mathrm{p}^{\mathrm{j}} \mathrm{i}\right.$

\footnotetext{
${ }^{9}$ In OT (Optimality Theory, by PRINCE; SMOLENSKY, 1993/2004), Faithfulness is a family of constraints preserving lexical contrasts. It requires that linguistic forms are realized as close as possible to their lexical 'basic forms' (KAGER, 1999, p.5). Change in input forms is possible in order to satisfy markedness constraints, but output candidates with less change are preferred. In other words, 'the more you change, the worse it is', 'the less you change, the better it is'. That is what we mean by 'change without change': minimal change concerning Faithfulness. Change is minimal when the result of spreading and delinking is the substitution of an element by the same kind of element.
} 


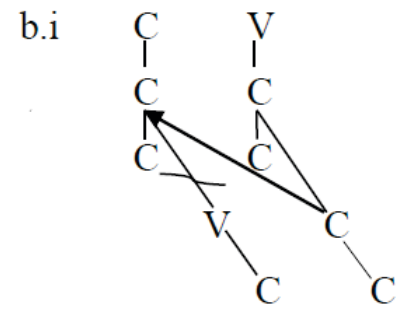

$/ \mathrm{k} / \quad$ i $/$

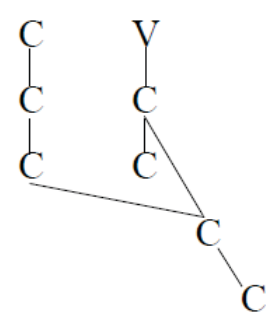

[ci] ou $[\mathrm{t} f \mathrm{i}]$

Although possible, palatalization that gives origin to complex structures and palatalization involving change are disfavoured processes. In BP, palatalization of these types is not allowed. Apparently, then, Faithfulness constraints are high ranked in BP (they cannot be violated).

\subsection{THE STRUCTURAL MOTIVATION OF PALATALIZATION. TYPICAL TRIGGERS AND TARGETS}

The high front vowel is the typical trigger of palatalization because it is consonantal in nature. Both its manner and place are Cc specified, representing its height (/i/is a high vowel) and coronality (/i/ is a front vowel). It is in this sense that /i/ is conceived as a 'hybrid' vowel: it is a V-root segment (vowel) with all its positions (manner and place) filled with C elements, as one sees in (8).

(8) The hybrid nature of the high front vowel

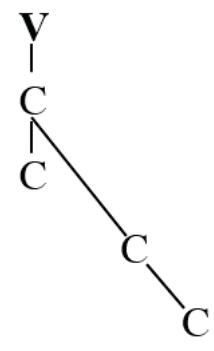

Vowels are V segments and consonants are C segments. V segments favour V features, C segments favour C features (van der HULST, 2005). We explain palatalization as the spreading of $\mathrm{C}$ features of high front vocoids onto the preceding consonant so that they gain appropriate licensing. This is the motivation of palatalization, expressed by the requirement in (9).

(9) The requirement of palatalization

PAL

C elements must be linked to a $\mathrm{C}$ root node.

Other vowels (the front mid high /e/ and the back high /u/) can trigger palatalization, but in an implicational way: in a certain language, they trigger palatalization if, and only if, /i/ is also a trigger (BATEMAN, 2007; KOCHETOV, 2011). This is due to the fact that the front high mid vowel /e/ is consonantal, but not as consonantal as /i/ in terms of manner (highness), as one sees in (10). Vowel /u/, which rarely triggers palatalization, represented in (11), is as high as /i/, but not as front (coronal/consonantal). Vowel $/ \mathrm{u} /$ is less consonantal than $/ \mathrm{i} /$ and $/ \mathrm{e} /{ }^{10}$.

\footnotetext{
${ }^{10}$ Height (manner) must be the property of / $\mathrm{u} /$ at play in palatalization. It means the spreading of manner, but not of place, something that the present proposal does not explain. This fact shall receive attention in future analyses.
} 
(10) Front mid high vowel: Cc place, but Vc manner

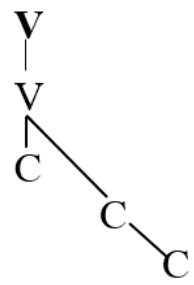

(11) Back high vowel: Cc manner, but Vv place

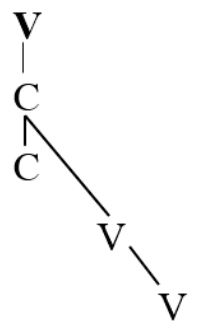

Considering the possible targets of palatalization, coronal stops are the typical ones because they are highly consonantal segments. They are both Cc-Place and Cc-Manner (12), just like the best trigger.

(12) Coronal stops

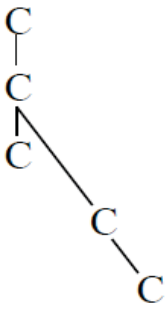

$/ \mathrm{t} /$

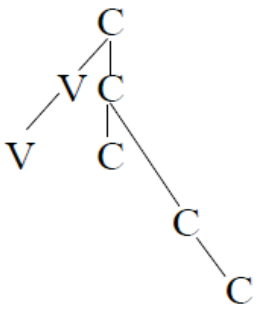

/d/

Coronal stops are maximally identical to the prototypical trigger in their featural representation. This is a consequence of 'change without change', or maximal identity between trigger and target: coronal stops are preferred over other possible targets of palatalization, high front vocoids are preferred over other triggers because they are both maximally consonantal and identical in featural terms. Consequently, the degree of change caused by the spreading-delinking of place and manner elements is minimal because the elements involved are the same, as one sees in (13).

(13) Change without change: full palatalization of a coronal stop

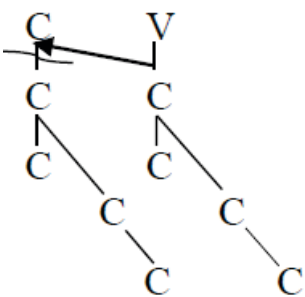

/t/ /i/

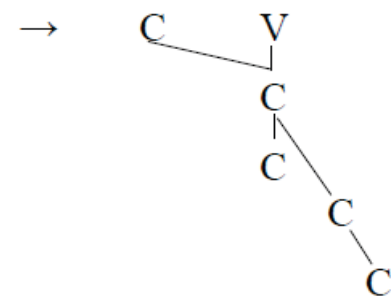

[ci] ou [t $\mathrm{fi}]$

Dorsal plosives $/ \mathrm{kg} /$, represented in (14), are the second best targets of palatalization because they are less consonantal than coronal stops. 
(14) Dorsal plosives: Cc manner, but Vc place

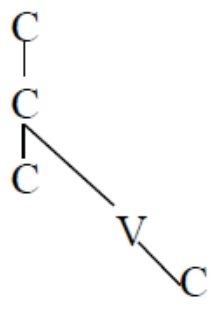

/k/

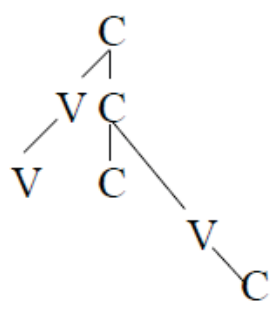

/g/

Such an internal configuration is what implicates elemental change when full palatalization of dorsal stops takes place, as one sees in (15), an operation that tends to be dispreferred (not allowed in BP, for example).

(15) Full palatalization of a dorsal plosive

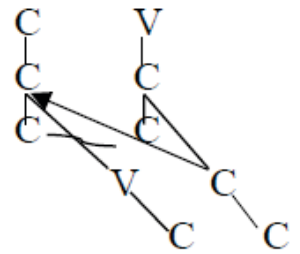

$/ \mathrm{k} / \mathrm{i}$<smiles></smiles>

[ci] or [tfi]

The degree of elemental similarity between trigger and target also explains why obstruents (stops more than fricatives) are better targets of palatalization than nasals, followed by laterals and finally by rhotics. As one sees in (16), obstruents are more consonantal than other kinds of segment: from obstruents to rhotics, there is increment in the vocalic character of segments.

(16) The internal structure of a stop, a fricative, a nasal, a lateral, a rhotic consonant

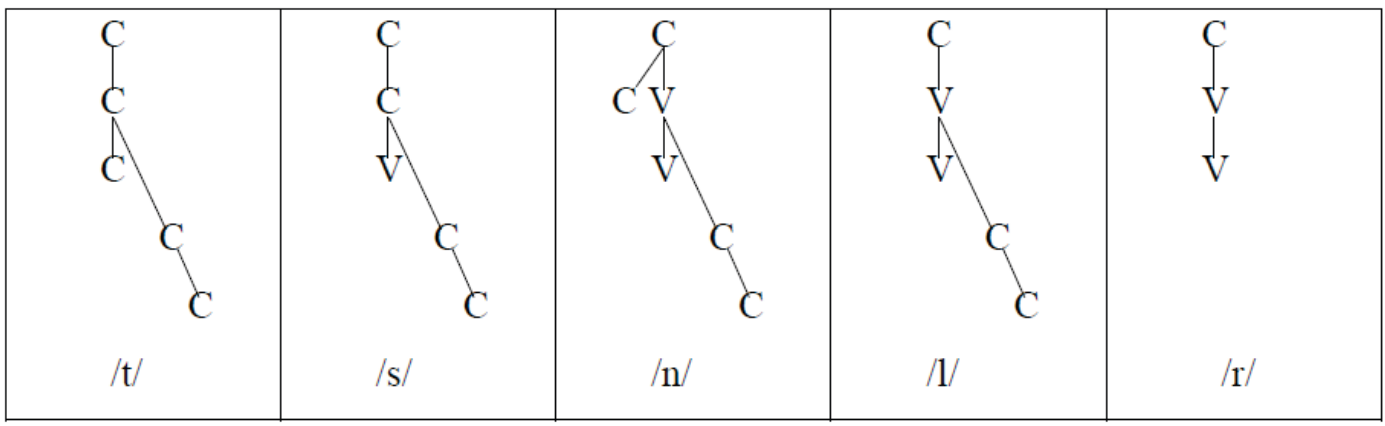

Palatalization causes less change in obstruents than in other segments because of their consonantal character.

The present analysis predicts that other assimilatory processes also select targets structurally similar to triggers. This should be observed in a process like labialization, for example: one expects that back round vowels (Vv-place) tend to affect dorsal and labial consonants, which are $\mathrm{Vv}$ and $\mathrm{Vc}$-place, respectively. One would also expect that at least one of the $\mathrm{V}$ elements spreads from the vowel to the consonant. The analysis of labialization in Judeo Spanish (BRADLEY, 2015, p. 66) confirms this expectation and shows that the language exhibits cross-linguistic tendencies: coronals tend to avoid secondary labialization, while labials and specially dorsals are preferred targets. 
Concerning palatalization, labial consonants are only secondarily palatalized because they are Vv-place segments. Only one of the Cc-place elements of the front vowel can spread. Delinking of elements does not happen. The result, represented in (17), is a complex structure. This type of palatalization implicates violation of Faithfulness and it is therefore not allowed in BP.

(17) Secondary palatalization of labial stops

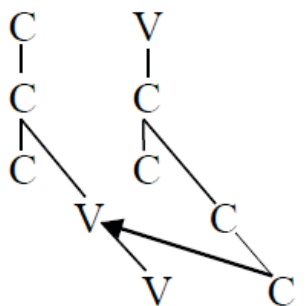

$/ \mathrm{p} / \quad / \mathrm{i} /$

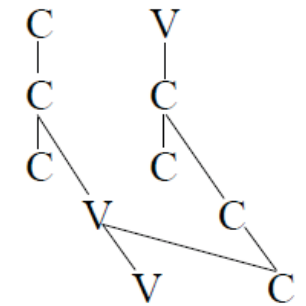

$\left[\mathrm{p}^{\mathrm{j}} \mathrm{i}\right]$

\subsection{THE SELECTION OF TRIGGER AND TARGETS OF PALATALIZATION IN BP}

$\mathrm{Vowel} / \mathrm{i} /$ is the only trigger of palatalization in $\mathrm{BP}$ and $/ \mathrm{t} \mathrm{d} /$ are the only targets of the process because the language has a requirement: trigger and targets of palatalization must be maximally consonantal and so maximally identical. The process results from the most restricted kind, the one that requires maximal identity between trigger and target, fully satisfying 'change without change'. In the perspective of OT (Optimality Theory, by PRINCE; SMOLENSKY, 1993,2004), one could say that BP has a highly ranked constraint against elemental change (IDENTELEMENT ${ }^{11}$ ). This is shown in representation (18), which repeats (6c).

(18) Palatalization in BP

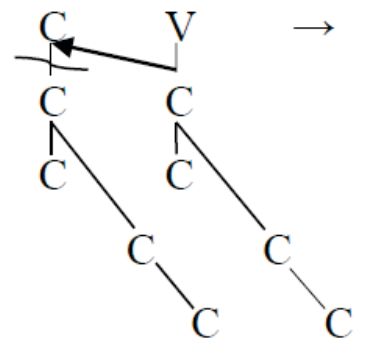

$/ \mathrm{t} /$

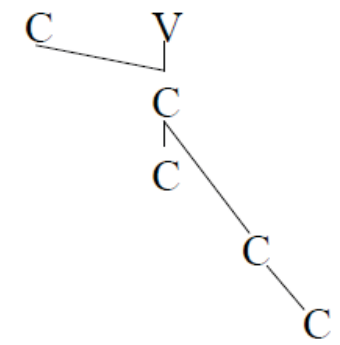

$\left[\mathrm{t} \int 1\right]$

The essential idea in the present analysis is that palatalization is triggered by PAL, the general palatalization constraint (see 9), but satisfaction of PAL cannot implicate violation of Faithfulness. That is why typical trigger and targets of palatalization are /i/ and /t, d/, respectively. One important question arises: why do not all languages of the world select $/ \mathrm{t}, \mathrm{d} /$ as targets the way BP does? A problem related to that involves explaining why in $\mathrm{BP} / \mathrm{s}, \mathrm{z}, \mathrm{n}, \mathrm{l} /$ are not targets of palatalization. As shown by representations (6a) and (6b), 'change without change' is possible with those segments: the spreading of a lower C-Place element from the vowel to the consonants (and the delinking of original C element from the anchor in full palatalization) would not implicate violation of Faithfulness while satisfying PAL.

Clearly, a constraint blocking palatalization independently of Faithfulness is necessary. The present analysis proposes a constraint forbidding branchingness: an element or node cannot have two mothers.

${ }^{11}$ In OT, Ident(F) is a family of faithfulness constraints that prohibits changing feature values (McCARTHY, 2008, p.37). 


\section{(19) NoBranCHING}

An element cannot be linked to more than one anchor.

The constraint in (19) can be relativized to the precise position of the element and of the process at hand. In a language like Dutch, for instance, which has no palatalization at all, (19) holds at all levels. The consequence is that, in Dutch, no C element can spread at all. In BP, NoBranching has to be relativized to the place dimension and to the lowest $\mathrm{C}$ of the manner dimension. At all these levels, NOBRANCHING is ranked higher than PAL, the palatalization constraint. Only the $\mathrm{C}$ that is daughter of the root node can spread.

\section{CONCLUSION}

The analysis showed that both the motivation and the selection of targets and trigger of palatalization in BP are structurally motivated and fit the typology of palatalization.

The motivation of palatalization is the high degree of consonantality of high front vocoids: these segments, typical triggers of the process, are both Cc-Place and Cc-Manner. As C elements are disfavoured in V-segments, C elements of high front vocoids tend to spread onto the preceding consonant in order to gain appropriate licensing.

Coronal stops are the prototypical targets of palatalization because they are highly consonantal and, most importantly, because they are maximally identical (in elemental terms) to the typical trigger. This fact is in accordance with Faithfulness constraints ('change without change'): the change resulting from the spreading and delinking of elements is minimal because the elements involved are intrinsically the same. A consequence of this principle is that consonants that are more similar to the prototypical trigger in elemental terms are targeted by palatalization more often.

Considering the targets of palatalization and their place, the analysis predicts that coronal stops are preferred over velars and labials. Between velar and labials, velars are preferred. Considering the triggers, the analysis predicts that /i/ is the best trigger of the process.

The proposal is in accordance with Clements and Hume (1995) in terms of the elements that spread, Cc-place elements, equivalent to the [coronal] feature in the V-Place node in that model. It is in accordance also with Bateman (2007) in what refers to the specification of the typical triggering vowel, [palatal, narrow] (in line with Articulatory Phonology), Cc-manner in this analysis. However, differently from those proposals, this analysis explains typological facts in a purely phonological (abstract) way, with elements $\mathrm{C}$ and $\mathrm{V}$.

Concerning the process, two kinds of palatalization were distinguished - secondary and full palatalization (BATEMAN, 2007) - in structural terms and analysed in a unified way. Secondary palatalization results from the spreading of one of the vowel's place element; full palatalization, from the spreading of the whole vowel's place. Another, more restrictive kind of full palatalization is possible when trigger and target are maximally identical: it is the spreading of the V's-place and manner onto the preceding consonant. It is this last kind of palatalization that affects the coronal stops in BP.

The proposal made here can potentially explain two variable and uncommon processes involving coronal stops in BP varieties. One is 'regressive' palatalization, triggered by a preceding palatal glide ${ }^{12}$ (CRISTÓFARO-SILVA, 2003), most probably resulting from

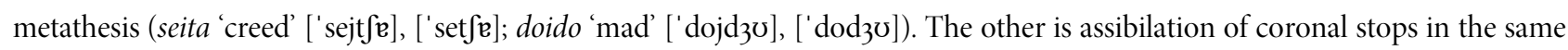
environment (Beti $\rightarrow$ Be $[t s] i$ 'Beth') (PAGOTTO, 2001; BRAGANÇA; AZEVEDO, 2015). Assibilation seems to affect only manner of the target consonants, which challenges our proposal of internal structure of segments and the spreading operations possible. Facing these challenges and further testing the model here proposed may be future developments of the analysis.

${ }^{12}$ There is no consensus in BP's phonological literature about the existence of underlying glides. 


\section{REFERENCES}

ABAUrre, M. B.; PAGOTTO, E. G. Palatalização das oclusivas dentais no português do Brasil. In: ABAURRE, M. B.; RODRIGUES, A.C.S. (org.). Gramática do português falado volume viii: novos estudos descritivos. Campinas, SP: Editora da UNICAMP, 2002. p. 557-602.

ANDERSON, J. M.; EWEN, C. J. Principles of dependency phonology. Cambridge: Cambridge University Press, 1987.

BATTISTI, E.; HERMANS, B. Palatalização no português brasileiro e nas línguas do mundo: Motivação estrutural, seleção de gatilhos e alvos. Lingüística, v.32, p. 61-75, 2016.

BATEMAN, N. A crosslinguistic investigation of palatalization. PhD dissertation, University of California, San Diego. Unpublished, 2007.

BERNS, J. Friction between phonetics and phonology: the status of affricates. PhD dissertation, Radboud Universiteit, Nijmegen. Published by LOT, Utrecht, 2013.

BISOL, L. Palatalization and its variable restriction. International Journal of the Sociology of Language, v.89, p.107-124, 1991.

BISOL, L; HORA, D. da. Palatalização da oclusiva dental e fonologia lexical. Actas do IX Encontro da Associação Portuguesa de Linguística, p. 61-80, 1993.

BOTMA, E. D. Phonological aspects of nasality: An element-based dependency approach. PhD dissertation, University of Amsterdam, Amsterdam. Published by LOT, Utrecht, 2004.

BRADLEY, T. G. Labialization and palatalization in Judeo-Spanish phonology. In: SMITH, J.; IHSANE, T. (ed.). Romance Linguistics 2012. Selected papers from the 42nd Linguistic Symposium on Romance Languages (LSRL). Amsterdam/Philadelphia: John Benjamins, 2015. p. 63-83.

BRAGANÇA, M. L. L.; AZEVEDO, L. K. A. de. Variação como espaço de investigação identitária: análise de uma pequena rede social familiar feminina de Florianópolis/SC. In: FREITAG, R. M. K.; SEVERO, C. G. (org.). Mulheres, linguagem e poder - Estudos de gênero na sociolinguística brasileira. São Paulo: Blucher, 2015. p.109-128.

CAGLIARI, L. C. Palatalização em português: Uma investigação palatográfica, Master’s Thesis, Universidade estadual de Campinas, Campinas/SP. Unpublished, 1974.

CARDOSO, S. A. M. da S. et al. Atlas linguístico do Brasil. Londrina: EDUEL, 2014.

CLEMENTS, G. N. The geometry of phonological features, Phonology Yearbook 2, p. 225-252, 1985.

CLEMENTS, G. N.; HUME, E. V. The internal organization of speech sounds. In: GOLDSMITH, J. A. (ed.). The handbook of phonological theory. Cambridge, Massachusetts/Oxford, Blackwell: 1995. p. 245-306.

CRISTÓFARO-SILVA, T. Palatalization in Brazilian Portuguese. In: PLOCH, S. (ed.). Living on the edge: 28 papers in honour of Jonathan Kaye. Studies in Generative Grammar 62. Berlin/New York: Mouton de Gruyter, 2003. p.243-257. 
CRISTÓFARO-SILVA, T. et al. 2012. Revisitando a palatalização no português brasileiro. Revista de estudos linguísticos, v.20, n.2, p.59-89, 2012.

DIAS, E. C. O. Uso variável das oclusivas alveolares /t, d/ em Florianópolis. Working Papers wm Linguística, número especial, p. 01$19,2010$.

FREITAG, R. M. K.; SOUZA, G. G. A. O caráter gradiente vs. discreto na palatalização de oclusivas em Sergipe. Revista Tabuleiro de Letras, v.10, n.2, p.78-89, 2016.

HORA, D. da; HENRIQUE, P. F. de L. Processos de assimilação envolvendo as consoantes oclusivas dentais /t, d/ no português brasileiro. Signum: Estudos da linguagem, v.18, n.1, p. 206-230, 2015.

KAYE, J. D.; LOWENSTAMM, J.; VERGNAUD, J. R. The internal structure of phonological elements: A theory of charm and government, Phonology 2, p.305-328, 1985.

KAGER, R. Optimality theory. Cambridge: Cambridge University Press, 1999.

KOCHETOV, A. Palatalization. In: van OOSTENDORP, M.; EWEN, C. J.; HUME, E. V.; RICE, K. (ed.). The Blackwell companion to phonology. Malden/Oxford/West Sussex: Blackwell, 2011. p.1666-1690.

McCARTHY, J. Doing optimality theory: Applying theory to data. Malden/Oxford/Carlton: Blackwell, 2008.

MONARETTO, V. N. de O. QUEDNAU, L.; HORA, D. da. As consoantes do português. In: BISOL, L. (org.). Introdução a estudos de fonologia do português brasileiro. 4th ed. Porto Alegre: EDIPUCRS, 2005. p. 207-238.

MORÉN, B. The parallel structures model of feature geometry. Working papers of the Cornell Phonetics Laboratory, 15, p. 194-270, 2003.

OliveIRA, A. A. de. Processos de palatalização das oclusivas alveolares em Maceió, PhD dissertation, Universidade Federal de Alagoas, Maceió. Unpublished, 2017.

PAGOTTO, E. G. Variação é identidade. PhD dissertation. Instituto de Estudos da Linguagem, Universidade Estadual de Campinas, Campinas. Unpublished, 2001.

PRINCE, A.; SMOLENSKY, P. Optimality theory: Constraint interaction in generative grammar. Technical report submitted to Rutgers University and University of Colorado-Boulder, later reviewed and published by Blackwell, 1993/2004. Available at Rutgers Optimality Archive, 537.

SOUZA, G. G. A. Palatalização de oclusivas alveolares em Sergipe, Master's Thesis, Universidade Federal de Sergipe, São Cristóvão/SE. Unpublished, 2016.

VAN DER HULST, H. The molecular structure of phonological segments. In: CARR, P.; DURAND, J.; EWEN, C. J. (ed.). Headhood, elements, specification and contrastivity: phonological papers in honour of John Anderson. Amsterdam/Philadelphia: John Benjamins, 2005. p.193-234. 
VAN DER HULST, H. Dependency-based phonologies. In: GOLDSMITH, J.; RIGGLE, J. YU, A. C. L. (ed.). The handbook of phonological theory. 2. ed. Malden/Oxford, Wiley-Blackwell, 2011. p.533-570.

\section{(c) (1) $(\$)$}

Received in April 9, 2020. Approved in April 24, 2020. 